\title{
Ribonucleic acid (RNA) biosynthesis in human cancer
}

\author{
Omar S Hajjawi
}

\begin{abstract}
In many respects, the most remarkable chemical substances within the genome of eukaryotic cells are remarkable proteins which are the critical structural and functional units of living cells. The specifications for everything that goes in the cell are natural digital-to-digital decoding process in an archive sequence by deoxyribonucleic acid (DNA) and an articulate construction by ribonucleic acid (RNA). The products of DNA transcription are long polymers of ribonucleotides rather than deoxyribonucleotides and are termed ribonucleic acids. Certain deoxyribonucleotide sequences, or genes, give rise to transfer RNA (tRNA) and other ribosomal RNA (rRNA) when transcribed. The ribonucleotide sequences fold extensively and rRNA is associated with specific proteins to yield the essential cell components, ribosomes. Transcription of other special sequences yields messenger RNAs (mRNAs) that contain ribonucleotide sequences that will be ultimately translated into new types of amino acid sequences of functional cellular protein molecules. This switch to a different variety of cellular molecular sequences is complex, but each sequence of the three ribonucleotides specifies the insertion of one particular amino acid into the polypeptide chain under production. Whilst mRNA is considered the vehicle by which genetic information is transmitted from the genome and allocated in the appropriate cytoplasmic sites for translation into protein via cap-dependent mechanism, the actual translation depends also on the presence of other so-called household and luxury protein molecules. Recent evidence suggests RNA species are required at initiation, because treatment of cells with antibiotics or drugs that inhibit RNA synthesis cause a decrease in protein synthesis. The rRNA is necessary as a structural constituent of the ribosomes upon which translation takes place, whereas tRNA is necessary as an adaptor in amino acid activation and elongation protein chains to ribosomes. In this article, we review malignant tumor, with stem like properties, and recent technical advances into the phenomenon of micro-particles and micro-vesicles containing cell-free nucleic acids that circulate plasma. New areas of research have been opened into screening tumor telomerase progression, prognosis of aptamers targeting cell surface, monitoring the efficacy of anticancer therapies, oncogenic transformation of host cell, and RNA polymerases role in the cell cycle progression and differentiation.
\end{abstract}

Keywords: Polymerases, Polyadenylation, Ribosomal RNA, Telomerase RNA, Aptamers, Carcinogenesis, Genometastasis, Antineoplastic agents, Signal Transducer and Activator of Transcription-STAT, Drug resistance

\section{Introduction}

Rudolf Virchow (1821-1902) is generally credited as the first to recognize leukemia cells [1], and Fridrich Miescher (1844-1895) had identified and isolated cellular substance containing nitrogen and phosphorus, whereas Albrecht Kossel (1853-1927) isolated the nucleic acids: two purines (adenine and guanine) and three pyrimidines (thymine, cytosine and uracil) [2]. Cancer is

Correspondence: omar.hajjawi@aauj.edu

Department of Biology, Arab American University, P. O. Box 240, Jenin, Israeli Occupied Territories of Palestine however defined as a group of more than 100 different diseases that is caused by multiple changes in cellular DNA and RNA, and it is characterized by uncontrollable growth (mitosis) in which cells are aggressive, invasive and sometimes metastatic [3]. Also, the discovery of the double helix of DNA molecule by Watson and Crick [4] was an added milestone in the twentieth century science (Figure 1). The genetic material of living organisms and double helix of DNA molecule formed the foundation of new discipline of molecular biology. 


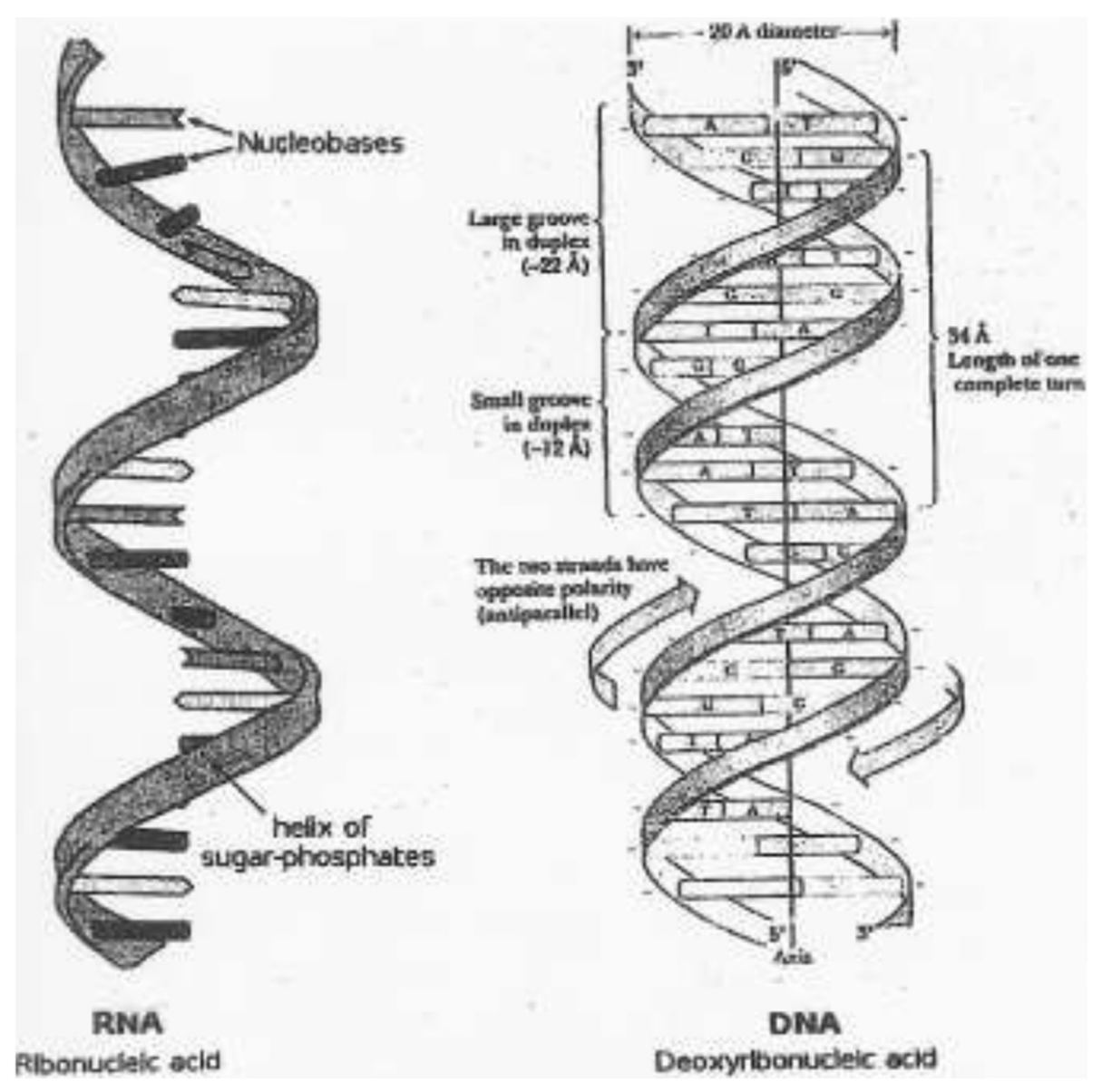

Figure 1 The essential single strand RNA and two strands DNA nucleic acids.

A complete turn of DNA double helix spans ten base pairs that cover a distance of $34 \AA$ A $(3.4 \mathrm{~nm})$. The individual base pairs are spaced $34 \AA$ A $(3.4 \mathrm{~nm})$ apart. The places where the strands cross hide base pairs that extend perpendicular to the viewer. The inside diameter is $11 \AA$ $(1.1 \mathrm{~nm})$, and the outside diameter $20 \AA$ ( $(2.0 \mathrm{~nm})$. Within the cylindrical outline of the double helix are two grooves that are large enough to house polypeptide chains. The largest human chromosome, chromosome number 1 , consists of approximately 220 million base pairs and is $85 \mathrm{~nm}$ long. The minus signs alongside the double helix strands represent many negatively charged phosphate groups along the entire length of each strand. Unlike double-stranded DNA, RNA is a single-stranded molecule in many of its biological roles and has a much shorter chain of nucleotides. However, RNA can, by complementary base pairing, form intra-strand double helixes, as in tRNA. While DNA contains deoxyribose, RNA contains ribose (in deoxyribose there is no hydroxyl group attached to the pentose ring in the 2 ' position). These hydroxyl groups make RNA less stable than DNA because it is more prone to hydrolysis. The complementary base to adenine is not thymine, as it is in DNA, but rather uracil, which is a nunmethylated form of thymine.

Adopted from: Watson J.D. and Crick, F.H.C. (1953) "Molecular structure of nucleic acid. A structure of deoxyribosenucleic acid", Nature, vol.171, pp.737-738; Gregory, S., Barlow, K.F., McLay, K.E., Kaul, R., Swarbreck, D., Dunham, A., Scott, C.E., Howe, K.L. and Woodfine, K. (2006). "The DNA sequence and biological annotation of human chromosome 1". Nature, vol. 441 (7091), pp.315-221; Nelson, D.L. and Cox, M.M. (2008) Lehninger Principles of Biochemistry, 5th edn, pp.277-287. New York, NY: W.H. Freeman and Company.

The detailed mechanism by which such genetic material could be expressed as the structural and catalytic proteins which play so important a role in the functioning of all living cells was still not obvious [5-7]. Stanley miller (1930-2007) and Harold Urey (1893-1981) designed an experiment that simulated hypothetical conditions thought to be present at the time of early life on earth $[8,9]$ and tested qualitatively for the occurrence of earthly chemicals that originated life [10]. The essential chemical elements 
of $\mathrm{H}_{2}, \mathrm{CH}_{4}, \mathrm{H}_{2} \mathrm{O}$ and $\mathrm{NH}_{3}$ which were confined to a sterile glass flasks and tubes, were subjected to electric discharges and the interaction produced 20 amino acids, the building block of proteins, as well as other organic compounds like: adenosine triphosphate, lipids, some sugars and the bases for RNA and DNA (Lazcano and Bada $[11,12])$.

Crick et al. [13] designed an elegant experimental strategy to determine the nature of the genetic code that was remarkably the correct one despite the absence of technology to analyze and compare DNA and protein sequence. The genetic code is the relation between the bases sequence in DNA (or its RNA transcripts) and amino acids sequence in proteins [14]. The features of the genetic code are as follows: (1) three nucleotide encode an amino acid, (2) the code is nonoverlapping, (3) the code has no punctuation, and (4) the genetic code is degenerate [14-16].

Proline only differs from this basic structure as it contains an unusual ring to the $\mathrm{N}$-end amine group, which forces the $\mathrm{CO}-\mathrm{NH}$ amide moiety into a fixed conformation $[17,18]$. Once this conceptual breakthrough had been made, the complex task of unraveling the many steps in protein biosynthesis could begin in the laboratory [19]. The sequence of amino acids in a protein is defined by a gene and encoded in the genetic code. Although this genetic code specifies 20 different L- $\alpha$-amino acids, the residues in a protein are often chemically altered in post-translational modification: either before the protein can function in the cell, or as part of control mechanisms $[17,20]$.

Genes are made of nucleic acids that contain the instructions for making proteins; enzymes are also made of proteins and they are needed to replicate genes [21-25].

Genetic information encoded in the two complementary strands of the DNA of any structural gene is transcribed by an enzyme called DNA-dependent RNA polymerase that catalyzes the synthesis of RNA from a DNA or RNA template [26]. The eukaryotic RNA polymerases (pol-I [27], pol-II [28] and pol-III [29,30] are the central multiprotein machines. The DNA-dependent RNA polymerase makes a single stranded RNA copy, complementary to one of the strands that are called mRNA. This attaches to a subcellular organelle ribosome which is composed of two subunits between 25 and $30 \mathrm{~nm}(250-300 \AA)$ in diameter with an rRNA to rotein ratio that is close to $1[18,19]$. It operates as a black box upon which the mRNA is translated $[31,32]$. The term translation encompasses all the steps by which the genetic content of the mRNA contained in the linear sequence of ribonucleotides is converted into a linear sequence of amino acids [26]. Whilst mRNA might be considered the means whereby genetic information is actually transmitted from the genome (the DNA), and placed in the appropriate cytoplasmic sites for translation into protein [33]. Organelle biogenesis and maintenance requires newly synthesized proteins, each of which needs to go from the ribosome translating its mRNA to the correct translocation to an organelle sub compartment [34]. Interestingly, it was demonstrated that fat and obesityassociated gene is located on chromosome 16 of mRNA demethylase [E.C. 2.1.1.270], i.e. methylation of mRNA plays a critical role in human energy homeostasis [35-37].

The nucleic acids are assembled from individual nucleotides just as proteins are assembled from individual amino acids. The nucleotides are synthesized by a series of enzyme mediated-mediated reactions [26,38,39]. Biochemical pathways are separately pursued for the synthesis of the ribose and the different bases that are then assembled to form nucleotide triphosphates [40]. The energy-carrying molecule ATP which consists of the base adenine, ribose, and three phosphate groups is also one of the nucleotide building blocks used in the synthesis of RNA, and the others being guanosine triphosphate, cytidine triphosphate and uridine triphosphate [41]. These nucleotides are usually synthesized by the transfer of energy from ATP to their diphosphate forms of the nucleotides [18]. Thus, there is a general pool of nucleotide triphosphates that work as building blocks for RNA within the cell $[42,43]$. These free nucleotides assembled into a linear sequence where the RNA molecule contains some of the coded information that is present in DNA, and when the DNA is copied into mRNA using base pairing of adenine-thymine, and guanine-cytosine is the process of DNA transcription [14]. During the synthesis of mRNA, the bonds between these pairs in DNA, adenine-thymine and guaninecytosine, and the double- stranded structure partially unwinds and the two strands separate [18]. The bases of the free nucleotide triphosphates and the bases in one of the separated DNA chains form new bonds. DNA therefore acts as a template to command the sequence of the bases in RNA. The base adenine in the free nucleotide would pair with the base thymine in DNA, and the base uracil in the free nucleotide would also pair with the base adenine in DNA. Similarly, the base cytosine in the free nucleotide pairs with the base guanine in DNA, and the base guanine in the free nucleotide pairs with base cytosine in DNA [44]. The resulting outcome would be a new sequence of bases in RNA which is an enantiomer mirror image of the base sequence in DNA [43]. Since the primary advantage of nucleotide base-pairing is that DNA two strands can replicate easily and accurately, each base can only pair to one other base (thymine to adenine, adenine to thymine, cytosine to guanine, and guanine to cytosine). Thus, if the original DNA codon contains the base sequence cytosine-guanine-thymine, 
the complementary codon sequence in mRNA is guaninecytosine-adenine [45-48].

Once the appropriate free nucleotide triphosphates are base-paired to the corresponding bases in DNA, the nucleotides are joined to each other by the enzyme RNApolymerase II (12 subunits) that causes pyrophosphate to be split off from nucleotide triphosphate in the process of linking one nucleotide to the next, forming the sugar-phosphate backbone of mRNA $[43,49,50]$. This enzyme is active only in the presence of DNA and it does not link the free nucleotide triphosphates together in its absence [46]. The enzyme moves along the DNA strand, linking one nucleotide at a time into the growing mRNA chain [47,51]. RNA-polymerase II activity is DNA-dependent, meaning that it must have a DNA template molecule before it can synthesize the RNA transcript. The DNA-dependent polymerase must also have $\mathrm{Mg}^{2+}$ and ribonucleoside $5^{\prime}$ triphosphates in order to carry out RNA synthesis. The RNA polymerase creates the new RNA strand from $5^{\prime}$ to $3^{\prime}$ [48].

Protein expression is determined by the rate of transcription and by post transcription processes that lead to changes in the mRNA transport, stability and translation efficiency [52]. These post-transcriptional processes are mediated by RNA modifications, secondary structure, micro RNAs (miRNAs), and RNA-binding proteins that recognize regulatory elements located in the 3 ' untranslated regions of transcripts [53]. The critical cellular process of polyadenylation that is the addition of poly (A) tail to mRNA that plays important roles in many aspects of the cellular metabolism of mRNA, though it begins as the transcription of a gene finishes or terminates. The $3^{\prime}$-most segment of the newly made pre-MRNA is first cleaved off by a set of proteins; these proteins then synthesize the poly (A) tail at any one of several possible sites [54]. The cleavage generates the free 3 '-hydroxyl group that defines the end of the mRNA to which adenine residues are immediately added by polyadenylate polymerase that catalyzes the reaction:

$$
\mathrm{RNA}+\mathrm{nATP}{ }^{\circledR} \mathrm{RNA}-(\mathrm{AMP})_{\mathrm{n}}+\mathrm{nPP}_{\mathrm{i}}
$$

where $\mathrm{n}=200-250[18,55]$. The poly (A) tail and its associated proteins are more likely to ptotect mRNA from enzymic destruction [56]. Protein-coding genes may have more than one polyadenylation site, "extra RNA", so a gene can code for several mRNAs that differ in their $3^{\prime}$-end [57], though mRNA polyadenylation is controlled by various cis-acting elements surrounding the cleavage site and their binding factors. Since alternative polyadenylation changes the length of the $3^{\prime}$ untranslated region, global shortening of $3^{\prime}$ untranslated regions through alternative polyadenylation is an emerging hallmark of cancer [58,59]; it can also change which binding sites for miRNAs the 3' untranslated region contains [60]. So, polyadenylation is a way of marking the RNA for degradation for many non-coding RNAs, including tRNA, rRNA,snRNA and snoRNA [61]. The RNA exosome (30-100 nm) is a conserved degradation machinery, which obtains full activity only when associated with cofactors; poly (A) tails have been found on human RNA fragments of both homopolymeric and mostly heterpolymeric tails [61-63]. Regulated polyadenylation of specific mRNAs is involved in oogenesis, cell cycle progression and synaptic plasticity [64]. Many polyadenylation trans-acting factors, including polyadenylate polymerase, are increasingly found to be involved in cell cycle, apoptosis and cancer prognosis [65]. So, genes undergoing alternative cleavage and polyadenylation during human cancer progression may be useful novel biomarkers and potentially targeted for disease prevention and treatment $[66,67]$.

The micro RNAs are an endogenous class of posttranscriptional regulators that regulate as many as onethird of human genes; they are small in length (21-25 nucleotide-long fragments) and single stranded [68]. Studies suggest that approximately half of known microRNA reside in non-protein coding RNAs (intron and extron) or within the intron of protein coding genes $[68,69]$. They can recognize and bind to imperfect basepairing complementary sequences in the 3 '-untranslated region of multiple target mRNAs, blocking translation of the gene expression or inducing cleavage of mRNA to control a multitude of critical processes through either reduction or inhibition in the translational efficiency of the target mRNA [70,71]. Recent studies have shown that miRNAs are aberrantly expressed in various human diseases, ranging from cancer to cardiovascular hypertrophy [72]. The micro RNAs target $\sim 60 \%$ of all genes, and they are abundantly present to repress $100 \mathrm{~s}$ of targets in all human cells; bioinformatics indicates that a 22 nucleotide single stranded RNA composed of 4 different ribonucleotides, they can have over $10^{13}$ possible sequence combinations. So, since the cell contains typically 1049 miRNAs, there must be a very high developmental and evolutionary selection pressure that utilizes only specific miRNA oligonucleotide sequences to yield biologically useful miRNA-mRNA interactions [73]. The biogenesis of miRNA is similar to other RNA starting from DNA transcription. A primary miRNA is an independent transcript processed by RNA polymerase II and they are bound in the nucleus by the 'microprocessor' complex that consists of ribonuclease III (an $\mathrm{Mg}^{2}$ ${ }^{+}$-dependent endonuclease), Drosha, and its co-factor, Pasha (DGCR8) [74]. The generation of mature miRNAs from precursor miRNAs by the ribonuclease III (Dicer1 /TRBP complex in the cytoplasm [75]. Dicer is a specialized ribonuclease that initiates RNA interference by 
cleaving double-stranded RNA into miRNA fragments [76], and TRBP (the human immunodeficiency virus transactivating response to double strand RNA-binding protein) is an integral component of a Dicer-containing complex $[75,76]$.

Neoplasia that includes many diseases is an abnormality of cellular differentiation, maturation and control of growth [77]. Rupert Allan Willis (1898-1980) defined neoplasm as "an abnormal mass of tissue, the growth of which exceeds and is uncoordinated with that of the surrounding normal tissues and persists in the same excessive manner after cessation of the stimuli that evoked the change", and this definition is the widely cited one [29]. Also, several neoplastic and non-neoplastic diseases were shown to contain circulating nucleic acids and that in cancer they originate mostly from tumor [78]. Hence, the level of circulating nucleic acids that have been associated with tumor burden and malignant progression, are utilized for cancer screening, prognosis, and monitoring the efficacy of an anticancer therapy [79].

Also, Conrad H. Waddington (1905-1975) had reported an intricate interplay between the cellular environment and genes effects on phenotype determination; he attributed the molecular signals to epigenetic phenomenon [80-82]. The epigenetic signals that are responsible for the establishment, maintenance and the reversal of metastable transcriptional states, have direct correlation with promoter hypermethylation and silenced tumor suppressor genes, upstream transcription factors and DNA repair enzymes [83,84]. Since cancer is ultimately a disease of genes, the mechanism by which epigenetic information is transmitted through cell division remain unclear as the complex epigenetic states are orchestrated by several converging signals [84-86].

The biologically active RNAs, including mRNA, tRNA, rRNA, small nucleic RNAs, [87] and other non-coding RNAs [64], contain self-complementary sequences that allow parts of the RNA to fold [88-90] and pair with itself to form double helices (Figure 2).

The analysis of these RNAs has revealed that they are highly structured and they do not consist of long double helices but rather collections of short helices packed together into structures akin to proteins. RNAs fold and conform to enzyme chemical catalysis $[88,91,92]$, for example, the active site of ribosome that analyzes peptide bond formation and release consists entirely of RNA $[87,93]$. The rRNA is necessary as a structural component of ribosomes upon which translation actually takes place and tRNA is required in amino acid activation, as an adaptor in mRNA directed amino acid specification

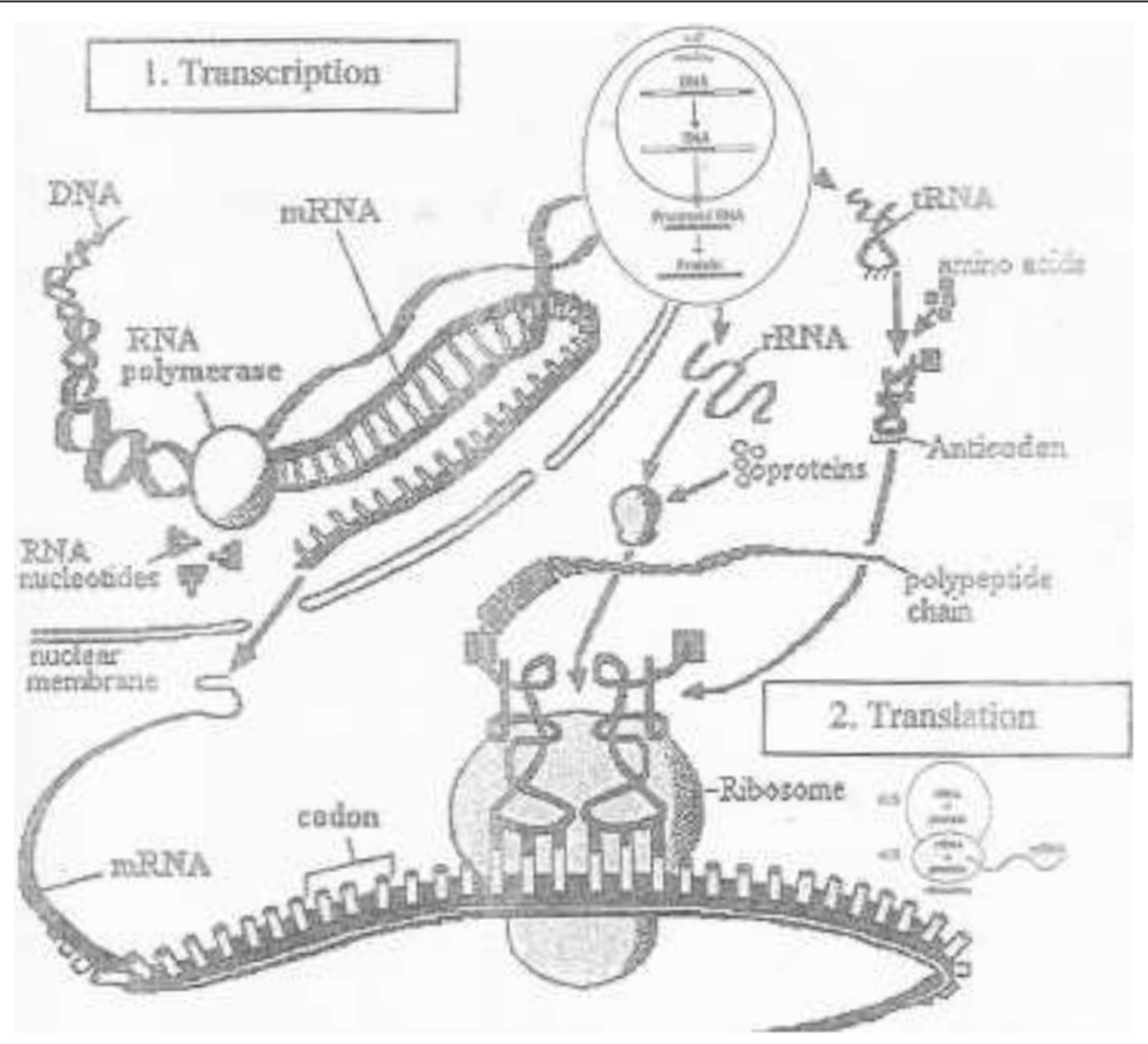

Figure 2 The fundamentals process of information transfer in cells. 
and in binding the growing protein chains to the ribosomes (Figure 2). In the process of DNA transcription the positioning of nucleotide units in the RNA molecules being made is under the control of the DNA that acts as a template $[18,94]$. The means by which this template dictates such a sequence involves both base pairing interactions and specific interactions between proteins and nucleic acids [95]. Each RNA chain is initiated at a specific site on the DNA template and subject to termination at another unique type of site on the template, i.e. there are defined units of transcription $[41,96]$. It is a selective process. Specific signals in the DNA template are recognized by the transcription apparatus. Initiation is governed by promoter regions in the DNA, and the region governing termination is designated a terminator [97].

(1) Transcription: Information encoded in the nucleotide sequence of DNA is transcribed through synthesis of mRNA whose sequence is dictated by the DNA sequence. (2) Translation: As the sequence of mRNA is decoded by the protein synthesis machinery, it is translated into the sequence of amino acids in a protein. This information transfer is encapsulated in the dogma: $\mathrm{DNA} \rightarrow$ RNA $\rightarrow$ Protein.

Adopted from: Hernández, G. (2012) On the Emergence and Evolution of the Eukaryotic Translation Apparatus, in Cell-Free Protein Synthesis, Biyani, M. (ed.), p.32. Retrieved September13, 2014 from http://cdn.intechopen. com/pdfs-wm/39965.pdf.

Archibald Garrod (1857-1936) was one of the first scientists to propose that inherited factors (genes) controlled the function of proteins [51]. Defects (diseases) in metabolism could be linked to the failure of specific enzymes to catalyze essential biochemical reactions. Protein synthesis, translation, is directed by an mRNA molecule. Translation can be seen to occur in two phases: (1) information transfer, in which RNA base sequence of the mRNA determines the sequence of amino acids and (2) chemical processes, in which the peptide bonds between the adjacent amino acids are formed. The components required for translation include: mRNA, ribosomes (60S and 40S), tRNA, aminoacyl tRNA synthetases, and accessory proteins involved in initiation, elongation and termination $[18,80]$. Elongation can be thought to involve three processes: (1) aligning each aminoacylated tRNA, (2) forming the peptide bond to add the new amino acid to the polypeptide chain, and (3) moving the ribosome along the mRNA by three more bases (one codon). Elongation proceeds until a stop codon is reached. There are three stop codons in the genetic code: UAG, UGA, UAA [98].

It is exceptionally difficult to assess the carcinogenic effects of so many agricultural, industrial, and household chemicals, but a significant hazard is posed by the disposal of various agricultural and industrial wastes that may contaminate drinking water, coastal water and marine life pollution [99-101]. Also, the identification of a chemical carcinogen is problematic because of the long lag between chemical exposure and the development of cancer, unless the effect is dramatic [102,103]. In view of the vast number of chemical substances that people encountered during their lives, Table 1 shows most strongly evidenced carcinogenic chemicals.

Virus is an ultramicroscopic virion wrapped in protective coating of protein, infectious agent, obligate intracellular parasites whose replication depends on its core DNA or RNA and protein synthetic process of the host cell for growth in tissue culture [104]. The major pathogenic of viruses are adenoviridae, flaviviridae, hepadnaviridae, herpesviridae, homyxoviridae, papovaviridae, paramyxoviridae, picornaviridae, polyomaviridae, orthomyxoviridade, rhabdoviridae and togaviridae [105]. The viral infection commonly reaches optimal time as a function of replication as clinical symptoms appear [106] , and the replication consists of the following steps: (1) attachment to and penetration of susceptible cell, (2) disassembly of nonstructural proteins to make nucleic acid available for virus multiplication, (3) synthesis of RNA or DNA through transcription and translation (Figure 2), (4) synthesis of structural and functional proteins, and (5) assembly and release mature viral particles from the cell $[81,104]$. Table 2 shows antiviral chemical agents that would clinically block virus replication when they are administered on the inset of disease, i.e. chemoprophylaxis.

\section{Methodology}

On infection, a viral RNA permeates human host cell membranes, whereupon it is either destroyed by several cellular RNases [E.C.3.1.26.4 RNase H; E.C. 3.1.26.5 RNase P; E.C. 3.1.27.3 RNase $\mathrm{T}_{1}$; E.C. 3.1.27.1 RNase $\mathrm{T}_{2}$; E.C. 3.1.27.4 RNase $V_{2}$; E.C.3.1.27.8. RNase $V_{1}$ and others], or it binds to ribosomes and it grows and divides to make proteins at an unregulated quickened pace $[107,108]$. The process of transcription cycle that consists of: preinitiation, initiation,promoter clearance, elongation and termination have a significant impact on the growth potential of tumours [109]. The failure of the host cell to recognize and destroy the viral infection is caused by the lack of particular co-stimulated molecules that aid in the way antigens react with lymphocytes [110-112]. Hence, the basic research into cancer entails identification of causes and developing strategies for prevention, diagnosis, treatments and cure [113-116]. The research spans chemotherapy, hormone therapy, immune therapy, nanomaterials, palliative surgery, radiation therapy and combined treatment modalities [77,94,117-121]; and the methods of evaluation were 
Table 1 Major chemical carcinogens in humans

\section{No. Chemical carcinogen}

1 Aflatoxin - B1 [CAS:1162-65-8] \& Aflatoxin - G1 [CAS:1165-39-5]: A group of toxic polynuclear (benzenoid type) metabolite molds produced chiefly by the fungus Aspergillus flavus; they are natural contaminants of a wide range of fruits, vegetables, cereal grains and improperly stored food. The $B_{1}$ and $G_{1}$ strains are known carcinogens

2 Aromatic amines [CAS: 8007-70-3]: Benzidine-based and naphthyamine are procarcinogens examples that enter the body through the skin, lungs or intestine. The gradation of potency of the carcinogenic amines depends on their hydrophobicity, and on electronic (reactivity, propensity to be metabolically transformed) and steric properties

Azo dyes [CAS: 84812-61-3]: Any of a broad series of synthetic dyes that have $-\mathrm{N}=\mathrm{N}$ - as a chromophore group. They are widely used in the food, pharmaceutical, cosmetic, textile and leather industries.

3 Asbestos [CAS: 1332-21-4]: A group of impure magnesium silicate minerals which occur in fibrous form. The various types serpentine, amphibole, amosite and crocidolite are highly toxic by inhalation of dust particles

4 Chemotherapeutic agents: Cytotoxic chemicals that are selectively destructive to malignant cells and tissues. They are classified into antimetabolites, anti-tumour, anthracyclines, topoisomerase inhibitors, plant alkaloids, and alkyting agents which are considered most important because they can add alkyl groups to the many electronegative groups under conditions which are present in some cells to modify DNA chemically. Examples of antineoplastic drugs:

Busulfan [CAS: 55-98-1]

Carboplatin [CAS: 41575-94-4]

Cisplatin [CAS: 9002-60-2]

Chlorambucil [CAS: 305-03-3]

Cyclophosphamide [CAS: 50-18-0]

Mechlorethamine [CAS: 51-75-2]

Oxaliplatin [CAS: 61825-94-3]

Thiotepa [CAS: $52-24-4]$

5 Heavy metals

Arsenic ${ }^{32}$ AS [CAS:7440-38-2]

Cadmium ${ }^{48}$ Cd [CAS: 7440-43-9]

Chromium ${ }^{24} \mathrm{Cr}$ [CAS:7440-47-3]

Nickel ${ }^{28} \mathrm{Ni}$ [CAS:7440-02-0]

6 Hydrocarbons:

Soot [CAS: 98615-67-9]: An airborne powder made of amorphous carbon, whereas its gas phase contains polycyclic aromatic hydrocarbons.

Tobacco [CAS: 8037-19-2]: Cured leaves of the species Nicotiana tabacum that contains acids (citric, oxalic, formic), alkaloids (nicotine, anabasine, myosmine), carbohydrates (lignin, pentosans, starch, sucrose), as well as tannin, ammonia, glutamine, and micro amounts of zinc, iodine, copper, manganese and polonium ${ }^{84} \mathrm{PO}_{210}$. Cigarette tar contains various aromatic ring compounds (especially benzo-[a] oyrene).

7 Vinyl chloride [CAS: 75-01-4]: $\mathrm{CH}_{2}=\mathrm{CHCl}$,

It is a manufactured substance that is used to prepare polyvinyl chloride to make plastic products for use in food packaging, medical products, appliances, cars, toys, credit cards and rainwear, and leaches into air and water.

The chemicals listed are those for which strong evidence exists. Source: Chandrasoma, P. and Taylor, C.T. (2000) Concise Pathology, 3rd edn. East Norwalk, CT: Appleton\& Lange; Kumar, V., Abbas, A.K. and Aster, J.C. (2014) Robins and Cotran Pathologic Basis of Disease, 9th edn. Philadelphia, PA: W.B. Saunders. mainly: (1) cytological methods (exfoliative and aspirational cytology), (2) flow cytometry, (3) hystological methods, (4) immunohistochemistry, (5) molecular diagnosis (aptamers), (6) tumor markers (hormones (calcitonin, catecholamine \& metabolites, ectopic, human chronic gonadotropin-HCG), oncofetal antigens ( $\alpha$-fetal protein, carcino embryonic antigen), iso enzymes, specific proteins, mucins and glycoproteins, new molecular markers).

RNA phage of each step of protein synthesis that could be possible to control, is indicative of individual inter-related biosynthesis of a given protein [122]. The rate of initiation complex formation dictates the amount of each of the viral proteins $[98,123]$. The RNA polymerases begin to replicate the viral RNA, a process of the most central mediators of malignant transformation [32,124]. RNA polymerase I [125], RNA polymerase II $[50,126,127]$ and RNA polymerase III $[128,129]$ transcribe protein-coding genes and they interact with factors involved in the synthesis of precursor rRNA 45S, chromatin remodeling, transcriptional activation, elongation, and RNA processing.

The multicellular eukaryotic human enzymes can be purified using isolated organelle, like nucleus, nucleoli, mitochondria and other internal organelles as a starting material, though simultaneous recovery of all three RNA polymerases is not always feasible due to diffusible nature of some of nuclear enzymes [18,110]. Jacob and Rose [130] had extensively reviewed the methods of solubilization, purification and difficulties of mammalian RNA polymerases.

HeLa cells were often the source for RNA polymerase complexes [131]; mitotic cells and cancer tissues with corresponding normal tissues that can be collected and frozen in liquid nitrogen at $-80^{\circ} \mathrm{C}$, are viably preserved until essayed $[127,132]$. Histopathological examination is done on the $10 \%$ formalin-fixed, paraffin-embedded tissue specimens which is an invaluable resource for clinical research though the nucleic acids extracted are fragmented and chemically modified making them challenging to use in molecular studies [133-135]. Histopathological observations are utilized in progression, metastatic susceptibility, therapeutic and radiation therapy sensitivity and prognosis $[136,137]$. Interestingly, the Raman spectroscopy non-invasive technique enables the observation of intracellular biological molecules without fixation or labeling procedures in situ $[137,138]$.

The bicinchoninic acid kit protein quantification assay [139] that is widely used to determine protein concentrations in the region $25-2000 \mu \mathrm{g} / \mathrm{ml}$. The cells are suspended and lysed in hypotonic buffer $(20 \mathrm{mM}$ Tris- $\mathrm{HCl}$

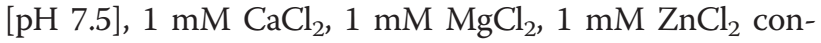
taining $1 \%$ Triton $\mathrm{X}-100$ ) for $5 \mathrm{~min}$ on ice; they were then separated into nucleolar and nucleoplasmic fractions by 
Table 2 Antiviral agents and some of their properties

\begin{tabular}{|c|c|c|}
\hline Drug & Description & Used for \\
\hline \multicolumn{3}{|l|}{$\begin{array}{l}\text { Purine and Pyrimidine } \\
\text { analogues }\end{array}$} \\
\hline Atripla & $\begin{array}{l}\text { An antiretroviral contains non-nucleoside (efavirenz) and } \\
\text { two nucleosides (emtricitabine and tenofovir disoproxil } \\
\text { fumerate) reverse transcriptase inhibitor. }\end{array}$ & $\begin{array}{l}\text { A fixed-dose regimen or in combination with other } \\
\text { antiretroviral drugs (rifampin) for the treatment of HIV } \\
\text { infection. }\end{array}$ \\
\hline Azidothymidine: Combivir & $\begin{array}{l}\text { An anti-HIV drug containing nucleoside reverse transcriptase } \\
\text { inhibitors, containing zidovudine and lamivudine. }\end{array}$ & $\begin{array}{l}\text { In combination with other antiretroviral drugs for } \\
\text { treatment of immunodeficiency for HIV infection. }\end{array}$ \\
\hline Retrovir & A nucleoside reverse transcriptase. & $\begin{array}{l}\text { In combination with other retroviral drugs to treat HIV } \\
\text { infection. }\end{array}$ \\
\hline Trizvir & An antiretroviral, nucleoside reverse transcriptase inhibitor. & $\begin{array}{l}\text { In combination with other drugs for treatment of HIV } \\
\text { infection. }\end{array}$ \\
\hline Complera & $\begin{array}{l}\text { An antiretroviral contains non-nucleoside (rilpivirine) and } \\
\text { two nucleosides (emtricitabine and tenofovir disoproxil } \\
\text { fumerate) reverse transcriptase inhibitor. }\end{array}$ & $\begin{array}{l}\text { A fixed-dose regimen or in combination with other } \\
\text { antiretroviral drugs for the treatment of HIV infection. }\end{array}$ \\
\hline Cymevene & $\begin{array}{l}\text { An antiviral preparation which is a DNA polymerase } \\
\text { inhibitor, containing ganciclovir. }\end{array}$ & $\begin{array}{l}\text { Cytomegalovirus-CMV in AIDS patients with reduced } \\
\text { immunity. }\end{array}$ \\
\hline Emtriva & $\begin{array}{l}\text { A nucleoside reverse transcriptase inhibitor that contains } \\
\text { emtricitabine. }\end{array}$ & $\begin{array}{l}\text { In combination with other antiretroviral drugs for } \\
\text { treatment of HIV infection. It is similar to lamivudine and } \\
\text { cross-resistance between the two is near similar. }\end{array}$ \\
\hline Epivir & $\begin{array}{l}\text { A nucleoside reverse transcriptase inhibitor, containing } \\
\text { lamivudine. }\end{array}$ & $\begin{array}{l}\text { In addition to other antiretroviral drugs to control and } \\
\text { treat HIV infection. }\end{array}$ \\
\hline Harvoni & $\begin{array}{l}\text { A nucleoside reverse transciptase inhibitor that contains } \\
\text { both ledipasvir and sofosbuvir. }\end{array}$ & An antiviral drug to treat chronic Hepatitus $C$. \\
\hline Herpid & An antiviral preparation containing idoxuridine. & $\begin{array}{l}\text { Skin infections caused by Herpes zoster and Herpes } \\
\text { simplex. }\end{array}$ \\
\hline Hivid & $\begin{array}{l}\text { A nucleoside reverse transcriptase inhibitor, containing } \\
\text { zalcitabine. }\end{array}$ & $\begin{array}{l}\text { A combination therapy with antiretroviral drugs for } \\
\text { treatment of HIV infection. }\end{array}$ \\
\hline Lamivudine: Combivir & $\begin{array}{l}\text { A nucleoside reverse transcriptase inhibitor that contains } \\
\text { both lamivudine and zidovudine. }\end{array}$ & $\begin{array}{l}\text { In combination with other antiretroviral drugs for } \\
\text { treatment of HIV infection. }\end{array}$ \\
\hline Epivir & A nucleoside reverse transcriptase inhibitor. & $\begin{array}{l}\text { In combination with other antiretroviral drugs for } \\
\text { treatment of HIV infection and disease. }\end{array}$ \\
\hline Trizivir & $\begin{array}{l}\text { A nucleoside reverse transcriptase inhibitor that contains } \\
\text { both lamivudine and zidovudine. }\end{array}$ & $\begin{array}{l}\text { In combination with other antiretroviral drugs for } \\
\text { treatment of HIV infection. }\end{array}$ \\
\hline Zeffix & A nucleoside reverse transcriptase inhibitor. & $\begin{array}{l}\text { Chronic Hepatitis B and evidence of viral replication in } \\
\text { patients with liver disease, inflammation and fibrosis. }\end{array}$ \\
\hline Rebetol & An antiviral preparation that contains tribavirin. & $\begin{array}{l}\text { In combination with interferon (pegintron) for the } \\
\text { treatment of chronic Hepatitis } C \text {. }\end{array}$ \\
\hline Stribild & $\begin{array}{l}\text { An antiretroviral tablet contains non-nucleoside (elvitegravir) } \\
\text { integrase strand transfer inhibitor, mechanism-based inhibitor } \\
\text { of cytochrome P450 (cobicistat) and two nucleosides } \\
\text { (emtricitabine and tenofovir disoproxil fumerate) reverse } \\
\text { transcriptase inhibitor. }\end{array}$ & $\begin{array}{l}\text { A fixed-dose regimen for the treatment of HIV infection } \\
\text { in adults who are antiretroviral treatment-naïve. }\end{array}$ \\
\hline Videx & $\begin{array}{l}\text { A nucleoside reverse transcriptase inhibitor that contains } \\
\text { didanosine. }\end{array}$ & $\begin{array}{l}\text { In combination with other antiretroviral drugs for } \\
\text { treatment of HIVinfection. }\end{array}$ \\
\hline Vira-A & An antiviral medication that contains vidarabin. & $\begin{array}{l}\text { Ointment treatment caused by Herpes simplex. It is an } \\
\text { alternative to acyclovir. }\end{array}$ \\
\hline Viracept & An antiviral protease inhibitor that contains nelfinavir. & $\begin{array}{l}\text { In addition to other antiretroviral drugs for treatment of } \\
\text { HIV infection. }\end{array}$ \\
\hline Viread & An antiviral nucleotide analogue that contains tenofivir. & $\begin{array}{l}\text { In combination with other retroviral drugs for treating } \\
\text { Hepatitis B and HIV infected patients with virological } \\
\text { failure. }\end{array}$ \\
\hline Virgan & An antiviral eye gel preparation that contains ganciclovir. & Acute inflammation of cornea, keratitis. \\
\hline Viroptic & An antiviral medication that contains trifluridine. & Eye drops treatment caused by mild viral infection. \\
\hline Zeffix & A nucleoside analogue that contains lamivudine. & $\begin{array}{l}\text { Chronic Hepatitis B and evidence of viral replication in } \\
\text { patients with liver disease, inflammation and fibrosis. }\end{array}$ \\
\hline
\end{tabular}


Table 2 Antiviral agents and some of their properties (Continued)

\begin{tabular}{ll}
\hline Zerit & $\begin{array}{l}\text { A nucleoside reverse transcriptase inhibitor that contains } \\
\text { stavudine. } \\
\text { An antiviral DNA polymerase inhibitor that contains } \\
\text { acyclovir. }\end{array}$ \\
Other drugs & An antiretroviral,nucleoside reverse transcriptase inhibitor \\
Abacavir : Trizivir & that contains abacavir, lamivudine and zidovudine. \\
Ziagen & A nucleoside reverse transcriptase inhibitor. \\
Amanatadine hydrochloride: & A viral replication inhibitor. \\
Lysovir & A dopaminergic, tricyclic amine preparation. \\
Symmetral & An antiretroviral, integrase strand transfer inhibitor. \\
Dolutegravir &
\end{tabular}

Foscavir

Gamma globulin:

Flebogamma

Gammabulin

A preparation of human normal immunoglobulin (5\%).

A freeze-dried preparation of human normal immunoglobulin.

Gammagard

OctagamSandoglobulinVigam

Vigam
Interferons alfa: Introna

Roferon-A

Viraferon

Interferons beta: Betaferon
A DNA polymerase inhibitor that acts in two stages to foscarnet.

A preparation of human normal immunoglobulin (5\%).

A preparation of human normal immunoglobulin (16\%).

A preparation of human normal immunoglobulin, freezedried powder comprising $0.5 \mathrm{~g}, 2.5 \mathrm{~g}, 5.0 \mathrm{~g}$ and $10.0 \mathrm{~g}$ in bottles with diluents for reconstitution and injection. suppress the replication of cytomegalovirus; it contains

A preparation of human normal immunoglobulin available as a solution and powder
In combination with other antiretroviral drugs for treatment of HIV infection.

Treatment and suppression of infections of skin and mucous membranes caused by Herpes simplex, Herpes zoster and varicella.

In combination with other antiretroviral drugs for the treatment of HIV infection.

In combination with other antiretroviral drugs for treating HIV infection.

Treatment and prevention of influenza $A$.

Parkinsonism.

Treatment of HIVinfection in conjunction with other antiretroviral drugs.

Life-threatening infections of viral origin especially those of eyes in AIDS patients with cytomegalovirus retinitis. Also, infections of mucous membranes and skin caused by Herpes simplex and AIDS patients who have not responded to treatment with acyclovir.

Immunoglobulin replacement therapy in patients who are immunodeficient, including, including various inherited disorders like hypogammaglobulinaemia (low levels of gammaglobulin in blood),

agammaglobulinaemia (absence of gammaglobulin in blood). Also, thrombocytopenia purpera (bleeding disorder), and helping to prevent recurrent infection by HIV infection.

Antibody deficiency syndrome.

Guillain-Barre syndrome (a severe,often rapidly progressive syndrome of muscular weakness and paralysis, believed to be an autoimmune disease), Kawasaki syndrome (a disorder affecting lymph nodes), thrombocytopaenia purpera (a clotting disorder involving blood platelets)

Replacement in various immunodeficiency states, including certain congenital conditions like thrombocytopaenia purpera. Also, prevention of recurring bacterial infections with HIV, Guillain-Barre syndrome, Kawasaki syndrome

Replacement treatment in primary and secondary immunoglobulin deficiencies, prevention of bacterial infections in children born with AIDS, thrombocytopenic purpura, Kawasaki disease, bone marrow transplants, Guillain-Barre syndrome.

Primary agammaglobulinaemia, hypogammaglobulinaemia, and other secondary secondary immunodeficiency disorders in children with AIDS,thrombocytopenia purpura,Kawasaki disease,bone marrow transplants and Guillain Barre syndrome

Neoplastic disorders (malignant conditions)

Hepatitis B and Hepatitis C (with or without tribavirin), neoplastic disorders.

Chronic Hepatitis B and chronic Hepatitis C infections.

Relapsing-remitting multiple sclerosis, and secondary progressive multiple sclerosis.

Multiple sclerosis with relapses. 
Table 2 Antiviral agents and some of their properties (Continued)

\begin{tabular}{|c|c|c|}
\hline Interferons Gamma: Immukin & A preparation of recombinant human interferon gamma- Ib. & $\begin{array}{l}\text { Additional treatment (with antibiotics) to lessen the } \\
\text { incidence of serious infections acquired by patients with } \\
\text { chronic granulomatous disease (any disese that gives rise } \\
\text { to masses of granulation tissue, e.g.tuberculosis and } \\
\text { leprosy). }\end{array}$ \\
\hline Paclitaxel & $\begin{array}{l}\text { A taxoid antineoplastic agent and mitotic inhibitor that is } \\
\text { based on plant alkaloid taxane or } 11(15->1) \text { abeotaxane. }\end{array}$ & $\begin{array}{l}\text { Treatment of tumor cancers: breast, ovarian, lung, } \\
\text { bladder, prostate, melanoma, esophageal and Kaposi } \\
\text { sarcoma. }\end{array}$ \\
\hline Rifadin & $\begin{array}{l}\text { An antibiotic and antimalarial preparation that contains } \\
\text { rifampicin. }\end{array}$ & $\begin{array}{l}\text { Prevention of meningococcal meningitis, carriers of } \\
\text { Haemophilus influenza, additional therapy for brucellosis, } \\
\text { Legionnaire's disease and serious staphylococcal } \\
\text { infections, tuberculosis and mycobacterial infections, } \\
\text { leprosy. }\end{array}$ \\
\hline Triumeq & $\begin{array}{l}\text { An antiviral medication that contains a non-nucleoside } \\
\text { integrase strand transfer inhibitor (dolutegravir), and two } \\
\text { nucleoside reverse transcriptase inhibitors (abacavir and } \\
\text { lamivudine). }\end{array}$ & A single-pill regimen for treatment HIV infection. \\
\hline Viramune & $\begin{array}{l}\text { A non-nucleoside reverse transcriptase inhibitor that contains } \\
\text { nevirapine. }\end{array}$ & $\begin{array}{l}\text { In combination with other antiretroviral drugs for } \\
\text { treatment HIV infection, progressive and/or advanced } \\
\text { immunodeficiency. }\end{array}$ \\
\hline \multicolumn{3}{|c|}{$\begin{array}{l}\text { Both DNA and RNA viruses can cause neoplasia. DNA viruses insert their nucleic acid directly into the genome of host cell and the virus replication normally } \\
\text { ensues. Examples: Papilloma, Herpes simplex, Molluscum contagiosum,and Hepatitis B. RNA viruses require RNA-directed DNA polymerase (reverse transcriptase), } \\
\text { an enzyme that causes production of a DNA copy of the RNA viral genome. Retroviruses examples: human T lymphocyte virus type I- HTLV-I, acquired immune } \\
\text { deficiency syndrome -AIDS, human immunodeficiency virus -HIV. } \\
\text { Adopted from: Medicines \& Prescription Drugs [102] New Lanark,ML: Geddes \& Grosset; Pisano, D.J. and Mantus, D.S. (2008) FDA Regulatory Affairs: A Guide for } \\
\text { Prescription Drugs, Medical Devices and Biologics, 2nd edn. New York, NY: Informa Healthcare USA, Inc.; Katzung, B.G., Masters, S.B. and Trevor, A.J. (2011) Basic \& } \\
\text { Clinical Phamacology, 12th edn. New York, NY: McGraw-Hill Medical Division. }\end{array}$} \\
\hline
\end{tabular}

zonal centrifugation in sucrose [140] at $15,000 \mathrm{rpm}$ for $15 \mathrm{~min}$ at $4^{\circ} \mathrm{C}$, and the supernatant was collected and frozen at $-20^{\circ} \mathrm{C}$ until re-use $[50,132]$. This method is a modified form of the Lowry et al. [141] and Bradford [142] methods that are also widely used dye-binding chromogenic protein variations assays [143]. The Bradford [142] protein assay is based on the association of specific amino acid residues, arginine, lysine, and histidine, with nonconjugated groups of Coomassie brilliant blue G-250 dye, in an acidic environment. When the dye-protein complex is formed, the $\mathrm{pK}_{\mathrm{a}}$ of the red-brown acidic solution converted to blue and it measured at $595 \mathrm{~nm}$. Bradford dye is convenient protocol to use, fast and relatively sensitive, but several compounds can interfere with the assay against typical standard curves for bovine serum albumin and bovine gamma globulin [144]. The other Lowry et al. [141] protein assay lies in the formation of peptide nitrogen(s) complex with $\mathrm{Cu}^{2+}$ under alkaline conditions ( $\mathrm{pH}$ 10.0-10.5), and the subsequent reduction of the FolinCiocalteay phosphomolybdic phosphotungstic acid reagent to heteropolymolybdenum blue at spectra $750 \mathrm{~nm}$, though ethylenediaminetetraacetic acid (EDTA) can interfere with chromophore production [145].

Radio-immunohistochemistry is a very sensitive in vitro technique in which a traceable radioactive isotope tags a marker to detect, identify and quantitate the concentration of specific ochemical neoplasia substance(s) [134,146-149]. Radioimmunoassay has been developed to identify and quantitate the concentration of RNA polymerase I [150], RNA polymerase II [151], RNA polymerase III [152] and mRNA [153]. Although it is less sensitive than enzymic activity as a measure of reverse transcriptase, but it can detect antigen using minute amounts of protein and in the presence of inhibitors for an RNA tumor virus-producing cells [154].

The three RNA polymerases transcribe the genome in the cell nuclei. The RNA polymerase II that is responsible for synthesizing mRNA and a large variety of noncoding RNAs, is mostly important; RNA production in growing cells is carried out by RNA polymerase I that transcribes the precursor of large rRNA, and by RNA polymerase III that transcribes rRNA, tRNA, and some noncoding RNAs [155]. Hossenlopp et al. [156] have used anti-polymerase I serum to classify the three RNA polymerases in order of their inhibition: I $>$ III $>$ I, indicating that polymerases I and II are more closely related than polymerases I and II $[32,157]$.

\section{Findings and interpretations}

The differential effect of selective inhibition on nuclear and nucleoplasmic RNA sysnthesis is related to the existence of distinct nuclear and chromosomal RNA polymerases that cause mitotic-like biochemical and morphological responses. Also. ribosome synthesis in HeLa cells is shown to be controlled at the level of processing rather than at the level of $45 \mathrm{~S}$ RNA transcription where chemical agents would cause the physiological and structural transitions of viral mitosis [158,159]. Table 2 
lists some of these therapeutic agents that can be considered to interfere with the process of virus replication.

In conclusion, the advent of sequencing human genome has facilitated the impressive advances in diagnosis, prognosis and treatment methodologies of invasive human tumor cells. A new area of research into chemical agents that interfere with mitosis-related cell death (apoptosis), are able to denature chemotherapy resistant neoplastic cells and inhibit protein expressions. Giri and Kumar $[55,160]$ have reported that the over expression of neo-poly (A) polymerase in human cancer cells signifies the importance of polyadenylation in cancer cellular events. The specificity of an electrostatic interaction between RNA and natural alkaloids or their synthetic analogs is found to be capable of inducing self-structure in polyadenelation. Hence, new novel compounds that exhibit excellent binding affinity to many RNA structures, can be utilized to modulate poly (A) structure in developing RNA targeted cancer therapeutics $[161,162]$. The nanoparticles of aptamers are also emerging to target the reaction of specific antigen epitopes with their binding sites. These are promising techniques in clinical diagnosis and therapy. Such new insights into genetics of tumors have prompted ground-breaking insights into development of new drugs that can treat, shrink and coax given tumors into prolonged remission.

\section{Competing interests}

The author declares that he has no competing interests.

Received: 17 November 2014 Accepted: 20 January 2015

Published online: 21 February 2015

\section{References}

1. Murgatroyd C. The power of the gene: the origin and impact of genetic disorder. New York, NY: Nova Science Publishers, Inc.; 2011.

2. Dahm R. Discovering DNA: Friedrich Miescher and the early years of nucleic acids research. Hum Genet. 2008;122(6):565-81.

3. Lorincz A. Nucleic acid testing for human disease. New York, NY: Taylor \& Francis Group, LLC; 2006.

4. Weaver JR, Susiarjo M, Bartolomei MS. Imprinting and epigenetic changes in the early embryo. Mamm Genome. 2009;20(9-10):532-43.

5. Reik W, Dean W, Walter J. Epigenetic reprogramming in mammalian delopment. Science. 2001;293(5532):1089-93.

6. Aplin JD. Developmental cell biology of human villous trophoblast: current research problems. Int J Dev Biol. 2010;54:323-9.

7. Haberle V, Li N, Hadzhiev Y, Plessy C, Previti C, Nepal C, et al. Two independent transcription initiation codes overlap on vertebrate core promoters. Nature. 2014;507:381-5.

8. Miller SL, Urey HC. Organic compound synthesis on the primitive earth. Science. 1959;130(3370):245-51.

9. Millette RL, Trotter CD. Initiation and release of RNA by DNA-dependent RNA polymerase. Proc Natl Acad Sci U S A. 1970;66(3):701-8.

10. Hajjawi O. Metal transport across human cell membranes. Eur Scientif J. 2014;10(6):252-70.

11. Lazcano A, Bada JL. The 1953 Stanley L. Miller experiment: fifty years of prebiotic organic chemistry. Origins Life Evol Biospheres. 2004;33(3):235-42.

12. Campbell MK, Farrell SO. Biochemistry. 5th ed. Belmont, CA: Thomson Learning, Inc; 2006.

13. Crick FHC, Barnett L, Brenner S, Watts-Tobin RJ. General nature of the genetic code for proteins. Nature. 1961;192:1227-32.

14. Berg JM, Tymoczko JL, Stryer L. Biochemistry. 5th ed. New York, NY: WH Freeman and Company; 2002.
15. Yasser M, Shaikh R, Chilakapati MK, Teni T. Raman spectroscopic study of radioresistant oral cancer sublines established by fractionated lonizing radiation. PLoS One. 2014;9(5):e97777. doi: 10.1371/journal.pone.0097777.

16. Koonin EV, Novzhilov AS. Origin and evolution of the genetic code the universal enigma. Int Union Biochem Mol Biol Life. 2009;61(2):99-111.

17. Dobson CM. The nature and significance of protein folding. In: Pain RH, editor. Mechanisms of protein folding. 2nd ed. New York, NY: Oxford University Press; 2000.

18. Nissen P, Hansen J, Ban N, Moore PB, Steitz TA. The structural basis of ribosome activity in peptide bond synthesis. Science. 2000;289(5481):920-30.

19. Dever TE. Molecular biology: a new start for protein synthesis. Science. 2012;336(6089):1645-6.

20. Lodish H, Berk A, Matsudaira P, Kaiser CA, Krieger M, Scott MP, et al. Molecular cell biology. 5th ed. New York, NY: WH Freeman and Company; 2004.

21. Joyce GF. RNA evolution and the origins of life. Nature. 1989;338(6212):217-24.

22. Frankel AD, Young JAT. HIV-1: fifteen proteins and an RNA. Annu Rev Plant Physiol Plant Mol Biol. 1998;67:1-25.

23. Vogel C, Marcotte EM. Insights into the regulation of protein abundance from proteomic and transcriptomic analyses. Nature Rev Genet. 2012;3:227-32.

24. Fletcher G, Mason S, Terrett J, Solviev M. Self-assembly of proteins and their nucleic acids. J Nanobiotech. 2003;1(1):1.

25. Kuwahara M, Li Y, Rozners E, Murakami H. Artificially created nucleic acids and peptide/protein in chemical biology. J Nucleic Acids. 2013;e219263. doi:10.1155/2013/219263.

26. Cramer P, Armache KJ, Baumli S, Benkert S, Brueckner F, Buchen C, et al. Structure of eukaryotic RNA polymerases. Annu Rev Biophys. 2008;37:337-52.

27. Grummt I. Regulation of mammalian ribosomal gene transcription by RNA polymerase I. Prog Nucleic Acid Res Mol Biol. 1999;62:109-54.

28. Lee Y, Kim M, Han J, Yeom KH, Lee S, Baek SH, et al. MicroRNA genes are transcribed by RNA polymerase II. EMBO J. 2004;23(20):4051-60.

29. Willis IM. RNA polymerase III: genes, factors and transcriptional specificity. Eur J Biochem. 1993;212(1):1-11.

30. Autexier C, Lue NF. The structure and function of telomerase reverse transcriptase. Annu Rev Plant Physiol Plant Mol Biol. 2006;75:493-517.

31. Cramer P, Bushnell DA, Kornberg RD. Structural basis of transcription: RNA polymerase II at 2.8 ångstrom resolution. Science. 2001;292:1863-76.

32. Bywater MJ, Pearson RB, McArthur GA, Hannan RD. Dysregulation of the basal RNA polymerase transcription apparatus in cancer. Nat Rev Cancer. 2013;13:299-314.

33. Sandberg R, Neilson JR, Sarma A, Sharp PA, Burge CB. Proliferating cells express mRNAs with shortened 3' untranslated regions and fewer microRNA target sites. Science. 2008;320(5883):1643-7.

34. Welsch WF, Lieber M. Ground water pollution from industrial waste. Sewage Industrial Wastes. 1955;27(9):1065-72.

35. Jia G, Fu Y, Zhao X, Dia Q, Zheng G, Yang Y, et al. N6-methyladenosine in nuclear RNA is a major substrate of the obesity-associated FTO. Nature Chem Biol. 2011;7(12):885-7.

36. Loos RJF, Yeo GSH. The bigger picture of FTO-the first GWAS-identified obesity gene. Nat Rev Endocrinol. 2014;10:51-61.

37. Watanabe T, Miura T, Degawa Y, Fujita Y, Inoue M, Kawaguchi M, et al. Comparison of lung cancer cell lines representing four histopathological subtypes with gene expression profiling using quantitative real-time PCR. Cancer Cell Int. 2010;10(2):e2867. doi: 10.1186/1475-2867-10-2.

38. Allen FW. The biochemistry of the nucleic acids purines and pyrimidines. Annu Rev Plant Physiol Plant Mol Biol. 1941;10:221-44.

39. Gott JM, Emeson RB. Functions and mechanisms of RNA editing. Ann Rev Genet. 2000;34:499-531.

40. Garrett RH, Grisham CM. Biochemistry. 4th ed. Boston, MA: Brooks/Cole, Cengage Learning; 2010.

41. Ugozzoli L, Wallace RB. Application of an allele-specific polymerase chain reaction to the direct determination of $A B O$ blood group genotypes. Genomics. 1992;12(4):670-4

42. Tsurugi K, Oqata K. Effects of cell sap, ATP, and RNA synthesis on the transfer of ribosomal proteins into nuclei and nucleoli in a rat liver cell-free system. Eur J Biochem. 1984;145(1):83-9.

43. Henras AK, Soudet J, Gérus M, Lebaron S, Caizerques-Ferrer M, Mougin A, et al. The post-transcriptional steps of eukaryotic ribosome biogenesis. Cell Mol Life Sci. 2008;65(15):2234-59.

44. Henriette MK, Mochizuki K. Non-coding RNA: a bridge between Small RNA and DNA. RNA Biol. 2009;6(2):138-40. 
45. Geiduschek EP, Haselkorn R. Messenger RNA. Annu Rev Plant Physiol Plant Mol Biol. 1969:38:647-76

46. Gregory S, Barlow KF, McLay KE, Kaul R, Swarbreck D, Dunham A, et al. The DNA sequence and biological annotation of human chromosome 1. Nature. 2006;441(7091):315-21.

47. Clancy S. Chemical structure of RNA. Nat Educ. 2008;7(1):60-70. Retrieved October 3, 2010, from http://www.nature.com/scitable/topicpage/ChemicalStructure-of-RNA-348.

48. Hernández G, Altmann M, Lasko P. Origins and evolution of the mechanisms regulating translation initiation in eukaryotes. Trends Biochem Sci. 2010;35(2):63-73.

49. Brenner S, Jacob F, Meselson M. An unstable intermediate carrying information from genes to ribosomes for protein synthesis. Nature. 1961;190:576-81.

50. Pattabiraman DR, Winberg RA. Tackling the cancer stem cells-what challenges do they pose? Nat Rev Drug Discov. 2014;13:497-512.

51. Nalwa HS, Webster T. Cancer nanotechnology- a nanomaterial for cancer diagnosis and therapy. Valencia, CA: American Scientific Publishers; 2006.

52. Meyer $K D$, Saletore $Y$, Zumbo P, Elemento O, Mason CE, Jeffrey SR, Comprehensive analysis of mRNA methylation reveals enrichment in 3 UTRs and near stop codons. Cell. 2012;149(7):1635-46.

53. Waddington $\mathrm{CH}$. Developmental mechanics of chick and duck embryos. Nature. 1930;125:924-5.

54. Ralston A, Shaw K. Gene expression regulates cell differentiation. Nat Educ. 2008;1(1):127-31.

55. Giri P, Kumar GS. Molecular aspects of small molecules-poly (A) interaction: an approach to RNA based drug design. Curr Med Chem. 2009;16(8):965-87.

56. Lianoglou S, Garg V, Yang JL, Leslie CS, Mayr C. Ubiquitously transcribed genes use alternative polyadenylation to achieve tissue-specific expression. Genes Dev. 2013;27:2380-96.

57. Danckwardt S, Hentz W, Kulozik AE. 3' end mRNA processing: molecular mechanisms and implications for health and disease. EMBO Life. 2008:27 (3):482-98.

58. Lin Y, Ozsolak F, Kim SW, Arango-Argoty G, Liu TT, Tenenbaum SA, et al. An in-depth map of polyadenylation sites in cancer. Nucleic Acids Res. 2012;40(17):8460-71.

59. Han T, Kim JK. Giving glioblastoma growth by alternative polyadenylation. Cell Res. 2014:24:1023-4.

60. Scherer WF, Syverton JT, Gey GO, Syverton G. Studies on the propagation in the vitro of poliomyelitis viruses. IV. Viral multiplication in a stable strain of human malignant epithelial cell (strain HeLa) derived from an epidermoid carcinoma of the cervix. J Exp Med. 1953:97(5):695-710.

61. Smith PK, Krohn RI, Hermanson GT, Mallia AK, Gartner FH, Provenzano MD, et al. Measurement of protein using bicinchoninic acid. Biogeosciences. 1985;150:76-85.

62. Tinoco I, Bustamante C. How RNA folds. J Mol Biol. 1999;293(2):271-81.

63. Lubas M, Christensen MS, Kristiansen MS, Domanski M, Falkenby LG, LykkAndersen $\mathrm{S}$, et al. Intraction profiling identities the human nuclear exosome targeting complex. Mol Cell. 2011;43(4):624-37.

64. Meijer HA, Bushell M, Hill K, Gant TW, Willis AE, Jones P, et al. A novel method for poly (A) fractionation reveals a large population of mRNAs with a short poly (A) tail in mammalian cells. Nucleic Acids Res. 2007;35(19):e132. doi:10.1093/nar/gkm830First published.

65. Tian B, Hu J, Zhang H, Lutz CS. A large-scale analysis of mRNA polyadenylation of human and mouse genes. Nucleic Acids Res. 2005;33(1):201-12.

66. Mukherjee $\mathrm{S}$. The emperor of All maladies: a biography of cancer. New York, NY: Simon \& Schuster, Inc.; 2010.

67. Xiao YL, Kash JC, Taubenberger JK. High-throughput RNA sequencing of a formalin-fixed paraffin-embedded autopsy lung tissue sample from the 1918 influenza pandemic. J Pathol. 2013;229(4):535-45.

68. Tan KH. Environmental soil science. New York, NY: Marcel Dekker, Inc.; 1995

69. Rosenberg LE. DNA and other strands: the making of human geneticist. Annu Rev Genome. 2014;15:1-26.

70. Friedman RC, Farh KK, Burge CB, Bartel DP. Most mammalian mRNAs are conserved targets of microRNAs. Genome Res. 2009;19:92-105.

71. Houzet $L$, Jeang KT. MicroRNAs and human retroviruses. Biochim Biophys Acta. 2011;1809(11-12):686-93.

72. Magbool R, Hussain MU. MicroRNAs and human disease: diagnostic and therapeutic potential. Cell Tissue Res. 2014;358(1):1-15.

73. Lukiw WJ. NF-KB- regulated micro RNAs (miRNAs) in primary human brain cells. Exp Neurol. 2012;235(2):484-90.
74. Morris AR, Bos A, Diosdado B, Rooijers K, Elkon R, Bolijn AS, et al. Alternative cleavage and polyadenylation during colorectal cancer development. Clin Cancer Res. 2012;18(19):5256-66.

75. Chendrimada TP, Gregory RI, Kumaraswamy E, Norman J, Cooch N, Nishikura K, et al. TRBP recruits the Dicer complex to Ago 2 for microRNA processing and gene silencing. Nature. 2005;436:740-4.

76. Lau PW, Potter CS, Carragher B, MacRae IJ. Structure of human Dicer-TRBP complex by electron microscopy. Structure. 2009;17(10):1326-32.

77. Duraiswamy J, Freeman GJ, Coukos G. Therapeutic PD-1 pathway blockade augments with other modalities of immunotherapy T-cell function to prevent immune decline in ovarian cancer. Cancer Res. 2013;73(23):6900-69012.

78. Casciano I, Di Vinci A, Banelli B, Brigati C, Forlani A, Allemanni G, et al. Circulating tumer nucleic acids: perspective in breast cancer. Breast Care (Basel). 2010;5(2):75-80.

79. Seguin L, Kato S, Franovic A, Camargo MF, Lesperance J, Elliott KC, et al. An integrin $\beta 3-K R A S-R a l B$ complex drives tumour stemness and resistance to EGFR inhibition. Nat Cell Biol. 2014;16:457-68.

80. Wang X, Lu X, Gomez A, Hon GC, Yue Y, Han D, et al. N6-methyladenosinedependent regulation of messenger RNA stability. Bature. 2014;2505 (7481):117-20

81. Revyakin A, Zhang Z, Coleman RA, Li Y, Inouye C, Lucas JK, et al. Transcription initiation by human RNA polymerase II visualized at single-molecule resolution. Genes Dev. 2012;26(15):1691-702.

82. Weis $B L$, Schleiff $E$, Zerges W. Protein targeting to subcellular organelles via mRNA localization. Biochim Biophys Acta Mol Cell Res. 2013;1833(2):260-73.

83. Kopelvich L, Crowell JA, Fay JR. The Epigenome as a target for cancer chemoprevention. J Natl Cancer Inst. 1995;5(23):1747-57.

84. Bonasio R, Tu S, Reinberg D. Molecular signals of epigenetic states. Science. 2010;330(6004):612-6.

85. Dawson MA, Kouzarides T. Cancer epigenetics: from mechanism to therapy. Cell. 2012;150(1):12-27.

86. Housman G, Byler S, Heerboth S, Lapinska K, Longacre M, Snyder N, et al. Drug resistance in cancer: an overview. Cancer. 2014;6(3):e1769. doi:10.3390/ cancers603176.

87. Zemora G, Waldsich C. RNA folding in living cells. RNA Biol. 2010;7(6):634-41.

88. Ferré-D'Amaré AR, Doudna JA. RNA folds: insights from recent crystal structures. Annu Rev Biophys Biomol Struct. 1999;28:57-73.

89. Tschochner H, Hurt E. Pre-ribosomes on the road from the nucleolus to the cytoplasm. Trends Cell Biol. 2003;13(5):255-63.

90. Schwarzenbach H, Hoon DSB, Pantel K. Cell-free nucleic acids as biomarkers in cancer patients. Nat Rev Cancer. 2011;11:426-37.

91. Frank DN, Pace NR. Ribonuclease P: unity and diversity in a tRNA processing ribozyme. Annu Rev Biochem. 1998;67:153-80.

92. Higgs PG. RNA secondary structure: physical and computational aspects. Q Rev Biophys. 2000;33(3):199-253.

93. Noble JE, Bailey MJA. Quantitation of protein. Methods Enzymol. 2009:463:73-95

94. Freeman GJ, Sharpe AH. A new therapeutic strategy for malaria targeting $\mathrm{T}$ cells exhaustion. Nat Immunol. 2012;13(2):113-5.

95. Jackson SP, Bartek J. The DNA-damage response in human biology and disease. Nature. 2009:461:1071-8.

96. Möller A, Xie SQ, Hosp F, Lang B, Phatmani HP, James S, et al. Proteomic analysis of mitotic RNA polymerase II reveals novel interactors and association with proteins dysfunctional in disease. Mol Cell Proteomics. 2012;11(6):e11767. doi:10.1074/mcp.M111.011767.

97. Schroeder R, Barta A, Semrad K. Strategies for RNA folding and assembly. Nat Rev Mol Cell Biol. 2004;5:908-19.

98. Sun G, Yan J, Noltner K, Feng J, Li H, Sarkis DA, et al. SNPs in human miRNA genes affect biogenesis and function. RNA. 2009;15(9):1640-51.

99. White RJ. RNA polymerases I and III, growth control and cancer. Nat Rev Mol Cell Biol. 2005;6:69-78.

100. Tanaka K, Nishioka J, Kato K, Nakamura A, Mouri T, Miki C, et al. Mitotic checkpoint protein hsMAD2 as a marker predicting liver metastasis of human gastric cancers. Jpn J Cancer Res. 2001;92:952-8.

101. Hogan CM. Water pollution. In: McGinley M, editor. Encylopedia of earth topic. Washington, DC: Cleveland National Council on Science and Environment; 2010

102. Verma S, Eckstein F. Modified oligonucleotides: synthesis and strategy for users. Annu Rev Biochem. 1998;67:99-134.

103. Miller MD, Marty MA. Impact of environmental chemicals on lung development. Environ Health Perspect. 2010;118(8):1155-64. 
104. Katzung BG, Masters SB, Trevor AJ. Basic \& clinical pharmacology. 12th ed. New York, NY: McGraw-Hill Medical Division; 2011.

105. Knipe DM, Howley PM. Fields virology. 6th ed. Philadelphia, PA: Lippincott Williams and Wilkins; 2013.

106. Chandrasoma P, Taylor CT. Concise Pathology. 3rd ed. East Norwalk, CT: Appleton \& Lange; 2000

107. Favoni RE, de Cupis A. The role of polypeptide growth factors in human carcinomas: new targets for a novel pharmacological approach. Pharmaco Rev. 2000;52(2):179-206.

108. Holzmann J, Frank P, Löffler E, Bennett K, Gerner C, Rossmanith W. RNase P without RNA: identification and functional reconstitution of the human mitochondrial tRNA processing enzyme. Cell. 2008;135(3):462-74.

109. Willis RA. The spread of tumors in the human body. London: Butterworth; 1952.

110. Alberts B, Johnson A, Lewis J, Raff M, Roberts K, Walter P. Molecular Biology. 4th ed. New York, NY: Garland Science; 2002.

111. Coulie PG, van den Eynde B, der Bruggen P, Boon T. Tumor antigens recognized by $T$ lymphocytes at the core of cancer immunotherapy. Nat Rev Cancer. 2014;14:135-46.

112. Penman S, Vesco C, Penman M. Localization and kinetics of formation of nuclear heterodisperse RNA. cytoplasmic heterodisperse RNA and polyribosome-associated messenger RNA in HeLa cells. J Mol Biol. 1968:34:49-69.

113. Kopnin BP. Targets of oncogenes and tumor supressors: key for understanding basic mechanisms of carcinogenesis. Biochemistry. 2000;65:2-27.

114. Hahn WC, Weinberg RA. Roles of making human tumor cell. New England J Med. 2002;347:1593-603.

115. Chin L, Gray JW. Translating insights from cancer genome into clinical practice. Nature. 2008;452(7187):553-63.

116. Fernandez TS, Fernandez CS, Mencalha AL. Human induced pluripotent stem cells from basic research to potential clinical applications in cancer. BioMed Res Int. 2013; 13. Retrieved October 22, 2014, from http://dx.doi.org/ 10.1155/2013/430290.

117. Sul JY, Kim TK, Lee JH, Eberwine J. Perspective on cell reprogramming with RNA. Biotechnology. 2012;30(5):243-9.

118. Nelson DL, Cox MM. Lehninger principles of biochemistry. 5th ed. New York, NY: WH Freeman and Company; 2008.

119. Ahmed SI. Lab diagnostics of neoplasia. San Francisco, CA: Sapphiresia; 2009.

120. Hayat MA. Methods of cancer diagnosis, therapy and prognosis. New York, NY: Springer Verlag; 2009.

121. Fadare O, Parkash V. Diagnosis of neoplasia in endometrial biopsies book and online bundle: a pattern-based and algorithmic. Cambridge: Cambridge University Press; 2014.

122. Pisano DJ, Mantus DS. FDA regulatory affairs: a guide for prescription drugs, medical devices and biologics. 2nd ed. New York, NY: Informa Healthcare USA, Inc:; 2008.

123. Kim J, Eberwine J. RNA: state of memory and mediator of cellular phenotype. Trends Cell Biol. 2010;20(6):311-8.

124. Slomovic S, Laufer D, Geiger D, Schusfer G. Polyadenylation of ribosomal RNA in human cells. Nucleic Acids Res. 2006:34(10):2966-75.

125. Morita Y, Shibutani T, Nakanishi N, Nishikura K, Iwai S, Kuraoka I. Human endonuclease $\mathrm{V}$ is a ribonuclease specific for inosine-containing RNA. Nat Communication. 2013;4:e2273. doi:10.1038/ncomms3273.

126. Maldonado E, Drapkin R, Reinberg D. Purification of human RNA polymerase II and general transcription factors. Methods Enzymol. 1996;174:72-100.

127. Montanaro $L$, Treré $D$, Derenzini $M$. The emerging role of RNA polymerase transcription machinery in human malignancy: a clinical perspective. Onco Targets Ther. 2013;6:909-16

128. Haurie V, Durrieu-Caillard S, Dumay-Odelot H, Da Silva D, Rey C, Prochazkova $M$, et al. Two isoforms of human RNA polymerase III with specific functions in cell growth and transformation. Proc Natl Acad Sci. 2010;107(9):4176-81.

129. Alla RK, Cairns BR. RNA polymerase III transcriptomes in human embryonic stem cells and induced pluripotent stem cells, and relationships with pluripotency transcription factors. PLoS One. 2014;9(1):e85648. doi:10.1371/ journal.pone.0085648.

130. Jacob ST, Rose KM. RNA polymerases and Poly (A) polymerase from neoplastic tissues and cells. Methods Cancer Res. 1978;14:191-241.

131. Schneider DA. RNA polymerase I activity is regulated at multiple steps in the transcription cycle: recent insights into factors that influence transcription elongation. Gene. 2012;493(2):176-84.
132. Thomadaki H, Tsiapalis CM, Scorilas A. Polyadenylate polymerase modulation in human epithelioid cervix and breast cancer cell lines, treated with etoposide or cordycepin, follow cell cycle rather than apoptosis. Biol Chem. 2005;386(5):471-80

133. Waterberg $\mathrm{JH}$. The lowery method for protein quantitation. In: Walker JM, editor. The protein protocols handbook. 2nd ed. Totawa, NJ: Humana Press Inc; 2002.

134. Yallow RS, Berson SA. Immunoassay of endogenous plasma insulin in man. J Clin Investigation. 1960;39:1157-75.

135. Hedegaard J, Thorsen K, Lund MK, Hein AMK, Hamilton-Dutoit SJ, Vang S, et al. Next-generation sequencing of RNA and DNA isolated from paired fresh-frozen and formalin-fixed paraffin-embedded samples of human cancer and normal tissue. PLoS One. 2014;9(5):e98187. doi:10.1371/journal. pone.0098187.

136. Cillo C, Schreyer M, Odartchenko N, Carrel S. Histological analysis of human tumour cell colonies grown in methylcellulose cultures. Br J Cancer. 1984:49:653-7

137. Panet A, Baltimore D, Hanafusa T. Quantitative of avian RNA tumor virus transcriptase by radioimmunoassay. J Virol. 1975;16(1):146-52.

138. Youngman EM, Brunelle JL, Kochaniak AB, Green R. The active site of the ribosome is composed of two layers of conserved nucleotides with distinct roles in peptide bond formation and peptide release. Cell. 2004;117(5):589-99.

139. Stella GM, Senetta R, Cassenti A, Margherita R, Cassoni P. Cancers of unknown primary origin: current perspective and future therapeutic strategies. J Translational Med. 2012;10(12):e5876. doi:10:1186/1479-5876-10-12.

140. Perry RP. Processing of RNA. Annu Rev Biochem. 1976;45:605-29.

141. Lowry OH, Rosebrough NJ, Farr AL, Randall RJ. Protein measurement with the Folin phenol reagent. J Biol Chem. 1951;193:265-75.

142. Bradford MM. A rapid and sensitive method for the quantitation of microgram quantities of protein utilizing the principle of protein dye binding. Anal Biochem. 1976;72:248-54.

143. Berges JA, Fisher AE, Harrison PJ. Comparison of Lowry, Bradfor and Smith protein assays using different protein standards and protein isolated from the marine diatom Thalassiosira pseudonana. Mar Biol. 1993;115:187-93.

144. Oshima Y, Shinzawa H, Takenaka T, Furihata C, Sata H. Discrimination analysis of human lung cancer cells associated with histological type and malignancy using Raman spectroscopy. J Biomed Opt. 2010;15(1):e3316296. doi:10.1117/1.3316296

145. Watson JD, Crick FHC. Molecular structure of nucleic acid: a structure of deoxyribosenucleic acid. Nature. 1953;171:737-8.

146. Greenwood FC, Hunter WM, Glover JS. The preparation of 125I-labelled human growth hormones of high specific radioactivity. Biochem J. 1963;89:114-23.

147. Brailly S, Lorenzo F, Jolivet A, Logeat F, Pallud C, Milgrom E. Radioimmunoassay of progesterone receptor in human tissues: application to breast cancer. J Endocrinol. 1988;116(3):427-34.

148. Akiyama F, Horii R. Therapeutic strategies for breast cancer based on histological type. Breast Cancer. 2009;16:168-72.

149. Straus H. Max Gerson: healing the hopeless. Kingston, Ontario: Quarry Books; 2001.

150. Stetler DA, Rose KM, Wenger ME, Berlin CM, Jacob ST. Antibodies to distinct polypeptides of RNA polymerase I in sera from patients with rheumatic autoimmune disease. Proc Natl Acad Sci U S A. 1982;79:7499-503.

151. Guialis A, Beaty BG, Ingles CJ, Crerar MM. Regulation of RNA polymerase II activity in alpha-amanitin resistant CHO hybrid cells. Cell. 1977;10:53-60.

152. Borchert GM, Lanier W, Davidson BL. RNA polymerase III transcribes human microRNAs. Nat Struct Mol Biol. 2006;13(12):1097-101.

153. Baldwin GS, Zhang QX. Measurement of gastrin and transforming growth factor a messenger RNA levels in colonic carcinoma cell lines by quantitative polymerase chain reaction. J Cancer Res. 1992;52:2261-7.

154. Parsons GG, Spencer CA. Mitotic repression of RNA polymerase ॥ transcription is accompanied by release of transcription elongation complexes. Mol Cell Biol. 1997;17(10):5791-802

155. Albert B, Leger-Solvestre I, Normand C, Ostermaier MK, Perez-Fernandez J, Panov Kl, et al. RNA polymerase I- specific subunits promote polymerase clustering to enhance the rRNA gene transcription cycle. J Cell Biol. 2011;192(2):277-93.

156. Hossenlopp P. Wells D, Chambon P. Animal DNA-dependendent RNA polymerases: partial purification and properties of three classes of RNA polymerases from uninfected and adenovirus-infected HeLa cells. Eur J Biochem. 1975;58:237-51. 
157. Gibb EA, Brown C, Lam WL. The functional of long non-coding RNA in human carcinomas. Molec Cancer. 2011;10(38):1-17.

158. Bonnart C, Gérus M, Hoareau-Aviella C, Kiss T, Caizergues-Ferrer M, Henry Y, et al. Mammalian HCA66 protein is required for both ribosome synthesis and centriole duplication. Nucl Acids Res. 2012;40(13):6270-89.

159. Hochstatter J, Hölzel M, Rohmoser M, Schermelleh L, Leonhardt H, Keouph $\mathrm{R}$, et al. Myb-binding protein 1a (Mybbp1a) regulates levels and processing of pre-ribosomal RNA. J Biol Chem. 2012;287(29):24385-77.

160. Giri P, Kumar GS. Isoquinoline alkaloids and their binding with polyadenylic acid: potential basis of therapeutic action. Mini Rev Med Chemist. 2010;10(7):568-77.

161. Hossain M, Kabir A, Kumar GS. Binding of the anticancer alkaloid sanguinarine with tRNAphe: spectroscopic and calorimetric studies. J Biomole Struc Dynamics. 2012;30(2):223-34.

162. Kumar GS. RNA targeting by small molecules: binding of protoberberine. benzophenanthridine Aristolochia alkaloids various RNA structures. J Bioscience. 2012;37:539-52.

\section{Submit your next manuscript to BioMed Central and take full advantage of:}

- Convenient online submission

- Thorough peer review

- No space constraints or color figure charges

- Immediate publication on acceptance

- Inclusion in PubMed, CAS, Scopus and Google Scholar

- Research which is freely available for redistribution 